\title{
Pengaruh Efektivitas Kepemimpinan dan Intensi Pelaksanaan Etika Kerja terhadap Kualitas Pelayanan Masyarakat Pada Pegawai Tingkat Kecamatan di Kota Bandung
}

\author{
Witri Wulandini ${ }^{1}$, Eeng Ahman ${ }^{2}$ \\ Mahasiswa Magister Manajemen Bisnis \\ Sekolah Pasca Sarjana Universitas Pendidikan Indonesia
}

\begin{abstract}
Abstrak
Penelitian ini secara umum memiliki tujuan untuk mengetahui gambaran yang jelas mengenai Efektivitas Kepemimpinan dan Intensi Pelaksanaan Etika Kerja terhadap Kualitas Pelayanan Masyarakat Pada Pegawai Tingkat Kecamatan di Kota Bandung. Dalam penelitian ini menggunakan metode deskriptif dengan pendekatan kuantitatif. Teknik pengumpulan data dilakukan dengan metode penyabaran angket. Populasi dalam penelitian ini berjumlah 90 orang. Untuk pengolahan data dalam penelitian ini menggunakan bantuan aplikasi program Microsoft Excel dan SPSS for Windows 20.0. Berdasarkan perhitungan dengan menggunakan pengukuran interval, diperoleh gambaran umum mengenai Efektivitas Kepemimpinan (Variabel $X_{1}$ ) berada dalam kategori baik dengan skor 4518. Untuk Intensi Pelaksanaan Etika kerja $\left(\mathrm{X}_{2}\right)$ berada pada kategori baik dengan skor 3288. Kualitas Pelayanan (Variabel Y) berada dalam kategori baik dengan skor 4690. Korelasi variabel $X_{1}$ dan $X_{2}$ terhadap variabel $Y$ memiliki hubungan yang signifikan. Artinya variabel kualitas pelayanan dapat diterangkan dengan variabel efektivitas kepemimpinan dan variabel intensi pelaksanaan etika kerja. Berdasarkan hasil pengujian statistik dapat disimpulkan bahwa "Terdapat pengaruh yang signifikan dan berkorelasi kuat antara Efektivitas Kepemimpinan dan Intensi Pelaksanaan Etika Kerja terhadap Kualitas Pelayanan Masyarakat Pada Pegawai Tingkat Kecamatan di Kota Bandung". Hal tersebut merupakan bukti bahwa secara keseluruhan Efektivitas Kepemimpinan berpengaruh positif dan berkontribusi secara signifikan terhadap kualitas pelayanan. Artinya dukungan dari pimpinan berpengaruh terhadap pegawai walaupun pengaruhnya rendah dan intense pelaksanaan etika kerja berpengaruh positif dan berkontribusi secara signifikan terhadap kualitas pelayan. Artinya dukungan dari teman sekantor berpengaruh terhadap kualitas pelayanan yang diberikan oleh pegawai kecamatan terhadap masyarakat.
\end{abstract}

Kata Kunci: Efektivitas Kepemimpinan, Intensi Pelaksanaan Etika Kerja, Kualitas Pelayanan

\section{PENDAHULUAN}

Pemberlakuan Undang-Undang No. 22 Tahun 1999 tentang Pemerintah Daerah yang kemudian direvisi dengan Undang-Undang No. 32 Tahun 2004 telah membawa perubahan paradigma yang mendasar dalam penyelenggaraan pemerintahan di Indonesia. Reformasi pemerintahan daerah ini diwujudkan dalam bentuk pergeseran model dan paradigma pemerintahan dari pendekatan "structural efficiency model" yang menekankan peningkatan efisiensi, efektivitas dan keseragaman. Penyelenggaraan pemerintahan menjadi pendekatan "local democracy model" yang menekankan nilai demokrasi dan keberagaman dalam penyelenggaraan pemerintahan lokal. Seiring dengan pergeseran model tersebut terjadi pula pergeseran dari pengutamaan dekonsentrasi ke pengutamaan desentralisasi (Hoessein, 2002:1), atau dari paradigma pemerintahan yang sentralistik kearah desentralistik.

Lembaga atau organisasi pemerintah semakin dituntut untuk menciptakan kualitas pelayanan yang dapat mendorong dan meningkatkan kegiatan ekonomi masyarakat. Karena itu, pelayanan (aparatur) pemerintah harus lebih proaktif dan cermat dalam mengantisipasi paradigma baru agar pelayanannya mampu memenuhi kebutuhan masyarakat yang dinamis. 
Saat ini kualitas merupakan bahasan yang penting dalam penyelenggaraan pelayanan, termasuk pada organisasi atau institusi pemerintah sebagai lembaga penyedia pelayanan publik.

Salah satu fungsi pemerintah kecamatan yang utama adalah menyelenggarakan pelayanan umum sebagai wujud dari tugas umum pemerintahan untuk mewujudkan kesejahteraan masyarakat. Birokrasi merupakan instrumen pemerintah untuk mewujudkan pelayanan publik yang efektif, efisien, berkeadilan, transparan dan akuntabel.

Adapun jenis pelayanan yang ada di beberapa kecamatan sebagai unit pemerintah yang memberikan berbagai jenis pelayanan ada pada tabel berikut ini.
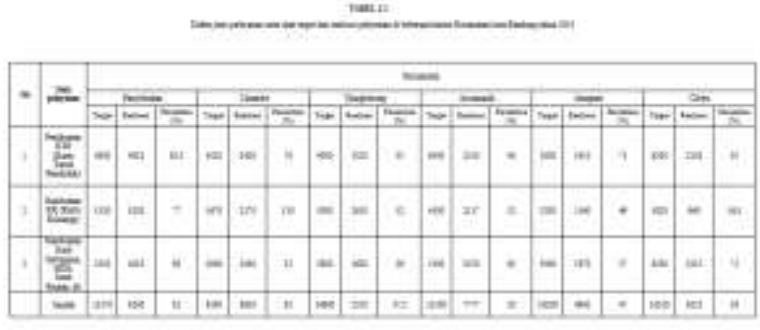

Dengan perolehan hasil kerja yang telah dipaparkan diatas ditiap kecamatan mengenai pelayanan pembuatan Surat Serbaguna ditahun 2010, maka kondisinya sesuai dengan jumlah masyarakat yang membutuhkan pelayanan tersebut. Berikut ini daftar jenis pelayanan serta data target dan realisasi pelayanan di kantor beberapa Kecamatan kota Bandung tahun 2011

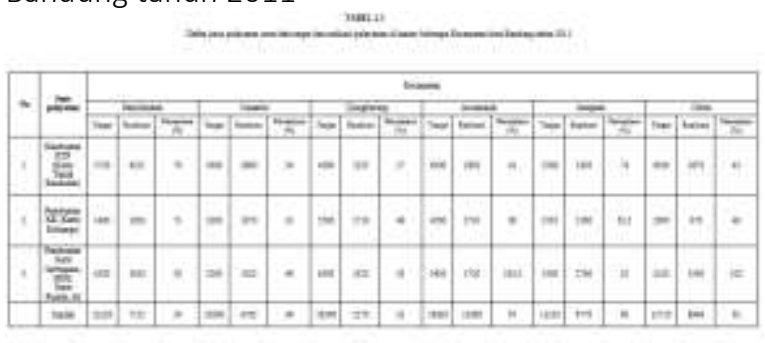

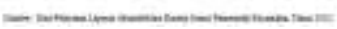

Berikut ini daftar jenis pelayanan serta data target dan realisasi pelayanan di kantor beberapa Kecamatan kota Bandung tahun 2012

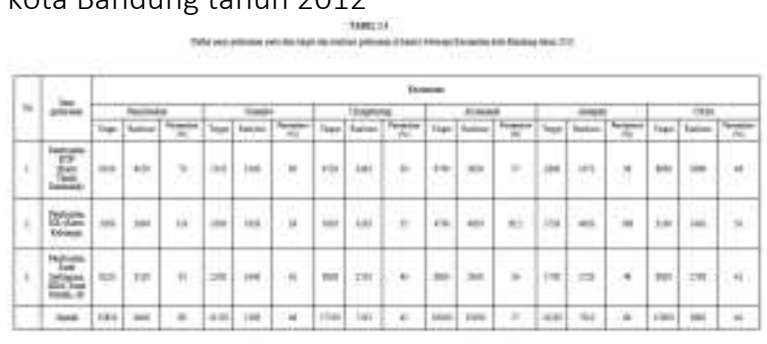

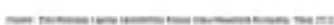

Dari enam kecamatan dalam melakukan pelayanan pembuatan serbaguna mengikuti jumlah masyarakat yang hanya sebagian kecil membutuhkannya. Sehingga demikian perolehan hasil kerjanya pun dibawah target yang telah ditetapkan.

Berikut ini daftar jenis pelayanan serta data target dan realisasi pelayanan di kantor beberapa Kecamatan kota Bandung tahun 2013

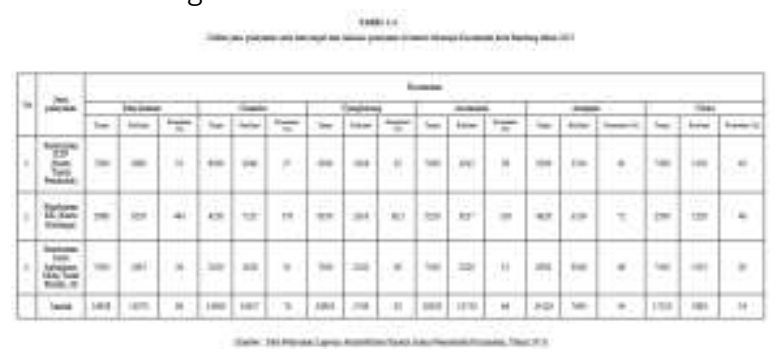

Untuk pelayanan pembuatan Surat Serbaguna, pada tahun 2013, pada enam kecamatan yang ada dalam penelitian awal ini semuanya memperoleh hasil pencapaian kerja dibawah 50\% yang artinya tidak dapat memenuhi target kerja dalam pelayanan yang telah ditetapkan. Masing- masing memperoleh hasil kecamatan Antapani 48\%, kecamatan Cinambo dan kecamatan Arcamanik memperoleh hasil yang sama yaitu sebesar 31\%, kecamatan Ujungberung sebesar $29 \%$, kecamatan panyileukan sebsar $24 \%$ dan yang paling rendah perolehan hasil kerja dalam pelayanan pembuatan surat serbaguna adalah kecamatan Cibiru sebesar $20 \%$. Jumlah masyarakat yang hanya sebagian kecil membutuhkannya, sehingga mempengaruhi perolehan hasil kerja dibawah target yang telah ditetapkan.

Berikut ini adalah bagan Standar Operasional Prosedur pembuatan Kartu Keluarga (KK) dan Kartu Tanpa Penduduk (KTP)

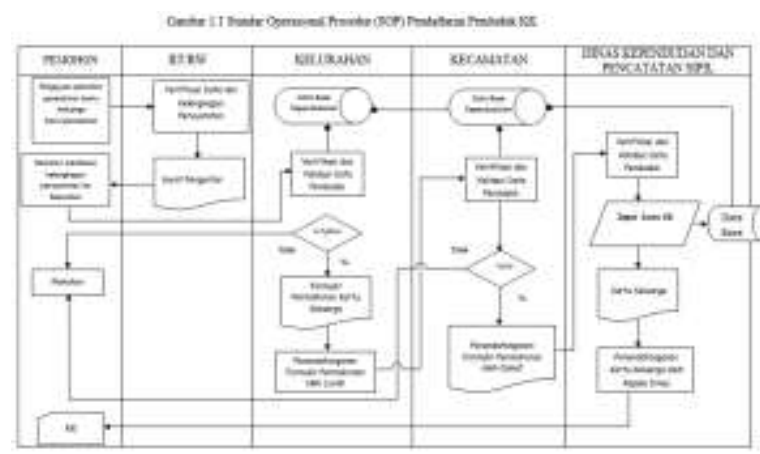




\section{a. Standar Operasional Prosedur (SOP) Pendaftaran Penduduk KTP}

1. Pemohon mengajukan permohonan penerbitan KTP

2. Verifikasi kelengkapan persyaratan oleh Ketua RT dan RW

3. Penerbitan surat pengantar oleh RT dan RW

4. Pemohon melengkapi persyaratan sebelum datang ke Kelurahan

5. Verifikasi dan Validasi data penduduk pada tingkat kelurahan

6. Setelah mengisi formulir dilakukan register dan penandatanganan formulir oleh lurah

7. Verifikasi dan validasi data penduduk pada tingkat Kecamatan

8. Verifikasi dan validasi data penduduk oleh operator komputer

9. Menginput data KTP sesuai dengan data base atau sesuai perubahan data pemohon yang dilengkapi oleh data pendukung

10. Pencetakan KTP

11. KTP yang telah dicetak dilakukan pemarafan oleh camat

12. Penandatanganan KTP oleh Kepala Dinas Kependudukan

13. Pengambilan KTP di Kecamatan

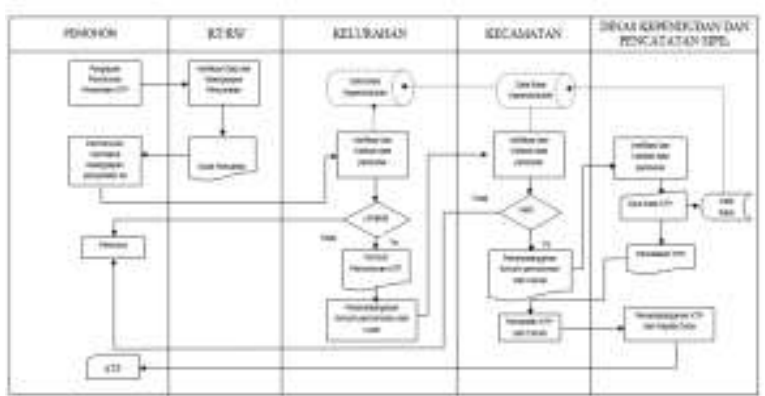

b. Standar Operasional Prosedur (SOP) Pendaftaran Penduduk KK

1. Pemohon mengajukan permohonan penerbitan Kartu Keluarga (KK) baru/perubahan

2. Verifikasi kelengkapan persyaratan oleh Ketua RT dan RW

3. Penerbitan surat pengantar oleh RT dan RW

4. Pemohon melengkapi persyaratan sebelum datang ke Kelurahan
5. Verifikasi dan Validasi data penduduk pada tingkat kelurahan

6. Setelah mengisi formulir dilakukan register dan penandatanganan formulir oleh lurah

7. Verifikasi dan validasi data penduduk pada tingkat Kecamatan

8. Verifikasi dan validasi data penduduk oleh operator komputer

9. Menginput data KK sesuai dengan data base atau sesuai perubahan data pemohon yang dilengkapi oleh data pendukung

10. Pencetakan KK

11. KK yang telah dicetak dilakukan pemarafan oleh camat

12. Penandatanganan KK oleh Kepala Dinas Kependudukan

13. Pengambilan KK di Kecamatan

- Dalam setiap pelayanan yang dilakukan di kecamatan masih ada beberapa oknum pegawai yang masih mengharapkan imbalan kepada pengguna jasa (masyarakat) atas jasa yang telah diberikan, walaupun pada ketentuannya tidak ada. Masyarakat sebagai pengguna jasa senantiasa mengeluhkan akan hal ini.

Kemunculan suatu tingkah laku ditandai dengan adanya niat (Intensi) individu untuk bertingkah laku. Intensi ini merupakan kemungkinan subjektif individu untuk melakukan tingkah laku tertentu (Fishbein dan Ajzen, 1975:288). Intensi ini terbentuk dari beberapa determinan yaitu bagaimana seseorang menyikapi suatu perilaku, bagaimana significant person mempengaruhi, mengharapkan ataupun menyetujui suatu perilaku yang muncul dan juga kemampuan seseorang mengontrol perilakunya.

Berdasarkan pengamatan awal di lapangan yang dilakukan oleh peneliti, peneliti melihat beberapa masalah diantaranya sebagai berikut :

1. Prosedur pelayanan yang diberikan kepada masyarakat setempat masih memakan waktu yang cukup lama. Masyarakat yang datang terutama masyarakat yang akan membuat / memperpanjang KTP tidak langsung dilayani tetapi harus mengisi daftar hadir terlebih dahulu, kemudian diminta untuk menunggu pegawai yang sedang berbincang-bincang dengan pegawai lainnya. 
2. Kedisiplinan waktu pegawai dalam melayani masih belum sesuai. Informasi yang diberikan pada masyarakat setempat waktu pelayanan pukul 08.0015.30, namun disaat masyarakat datang ke kantor kecamatan pada pukul 08.30 belum dapat dilayani dikarenakan petugas belum hadir. Masyarakat yang hadir pada pukul 15.00 pun tidak dapat dilayani dengan alasan petugas sudah pulang.

3. Kesopanan serta keramahan petugas pelayanan masih terlihat kurang saat memberikan pelayanan, tidak adanya senyum, sapa dan salam. Hal ini terjadi disemua kasi yang ada di kantor kecamatan panyileukan terutama pada kasi pelayanan yang lebih sering berhubungan langsung dengan masyarakat.

Berdasarkan uraian diatas maka perlu dilakukannya penelitian terhadap masalah kualitas pelayanan, khususnya yang menyangkut dengan masalah kualitas pelayanan pegawai di kantor kecamatan. Judul penelitian yang diambil adalah "Pengaruh Efektivitas Kepemimpinan dan Intensi Pelaksanaan Etika Kerja terhadap Kualitas Pelayanan kepada Masyarakat pada Pegawai tingkat Kecamatan di Kota Bandung ".

\section{KERANGKA PENELITIAN \& HIPOTESIS}

Dalam penelitian ini masalah berawal dari pelayanan yang diberikan oleh pegawai kecamatan yang tidak sesuai dengan jam pelayanan yang ada, prosedur pelayanan yang masih memakan waktu yang cukup lama, serta kurang ramahnya pegawai kecamatan dalam melayani masyarakat. Selain itu pimpinan (camat) lebih sering telat saat hadir di kantor, menuntut pegawainya untuk bisa bekerja dengan baik tanpa didukung oleh pimpinannya sehingga berdampak pada bawahananya (pegawai) yang ikut hadir tidak sesuai jam kerja dan menyebabkan keterlambatan di seksi pelayanan. Rekan kerja didalam satu seksi yaitu seksi pelayanan pun satu sama lain saling mengandalkan untuk hadir tepat waktu di kantor. Dengan demikian pegawai pun hampir semuanya hadir datang terlambat. Banyaknya keluhan dari masyarakat yang penulis temui dilapangan saat penulis datang di salah satu kecamatan yang ada di Bandung, selain jam pelayanan yang mengalami keterlambatan, sikap pegawai pun tidak begitu ramah dan tidak berusaha untuk mendengarkan apa yang menjadi keluhan dari masyarakat menjadi perhatian penulis dalam penelitian ini. Menurut Parasuraman (1990:33) sesuai dengan yang diharapkan, maka pelayanan dipersepsikan baik dan memuaskan. Jika pelayanan yang diterima melampaui harapan pengguna jasa, maka kualitas pelayanan dipersepsikan sebagai kualitas ideal. Sebaliknya apabila pelayanan yang diterima lebih rendah dari yang diharapkan, maka kualitas pelayanan dipersepsikan buruk. Jadi baik buruknya kualitas pelayanan tergantung dari kemampuan penyedia pelayanan dalam memenuhi harapan pengguna jasa secara konsisten.

Bila dilihat dari permasalahan yang telah dipaparkan diatas bahwa kualitas pelayanan yang telah diberikan oleh pegawai tingkat kecamatan di seksi pelayanan disebabkan pimpinan dan rekan kerja sering datang terlambat, walaupun bagi pegawai kecamatan datang terlambat adalah sikap yang kurang baik dan tidak sesuai dengan aturan yang ada. Hal ini sejalan dengan keyakinan normatif berkenaan dengan harapan-harapan yang berasal dari referent atau orang dan kelompok yang berpengaruh bagi individu (significant others) seperti orang tua, pasangan, teman dekat, rekan kerja atau lainnya, tergantung pada perilaku yang terlibat.

Berdasarkan permasalahan diatas maka penelitian ini akan mengukur dan menganalisa mengenai pengaruh efektivitas kepemimpinan dan intensi pelaksanaan etika kerja pada pegawai tingkat kecamatan di kota Bandung terhadap kualitas pelayanan. Adapun teori yang digunakan dalam penelitian ini adalah teori mengenai kualitas pelayanan dari Philip Kotler. Teori ini mengkaji mengenai indikator-indikator yang mempengaruhi kualitas pelayanan. Tingkat kepuasan pelanggan terhadap pelayanan yang diberikan dapat dilihat dari penggunaan teknologi yang canggih, waktu pelayanan yang efektif dan efisien, serta sarana dan prasarana yang memadai sehingga pelayanan dapat dilakukan secara maksimal. Teori lain yang mendukung dalam penelitian ini adalah teori mengenai efektivitas kepemininan yang dikemukakan oleh Semuil Tjiharjadi, 
serta theory planned behavior yang dikemkanan oleh Ajzein.

Dari telaah pustaka dimuka, maka disusun suatu kerangka pemikiran teoritis yang menyatakan pengaruh antara variabel dalam penelitian ini, untuk lebih jelasnya kerangka pemikiran teoritis digambarkan dalam gambar 2.1

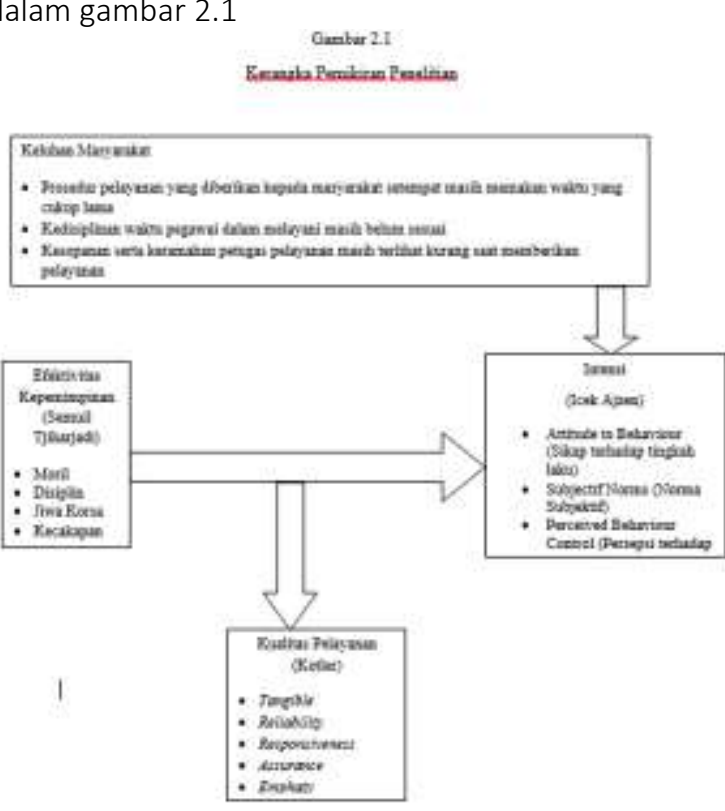

Hipotesis Penelitian

Berdasarkan pada kerangka pemikiran teoritis di atas, maka hipotesis penelitian yang diajukan dalam penelitian ini adalah sebagai berikut:

$\mathrm{H}_{1}$ : Efektivitas kepemimpinan berpengaruh terhadap intensi pelaksanaan etika kerja pegawai tingkat kecamatan di kota Bandung.

$\mathrm{H}_{2}$ : Efektivitas kepemimpinan berpengaruh terhadap kualitas pelayanan pegawai tingkat kecamatan di kota Bandung.

$\mathrm{H}_{3}$ : Intensi pelaksanaan etika kerja berpengaruh terhadap kualitas pelayanan pegawai tingkat kecamatan di kota Bandung.

$\mathrm{H}_{4}$ : Efektivitas kepemipinan dan intesi pelaksanaan etika kerja berpengaruh terhadap kualitas pelayanan pegawai tingkat kecamatan di kota Bandung.

\section{METODE PENELITIAN}

Penelitian ini mengambil lokasi di kota Bandung, dengan subjek penelitian yaitu pegawai negeri sipil tingkat kecamatan kota Bandung. Dalam penelitian ini, pegawai yang menjadi responden merupakan pegawai yang berada di kasi pelayanan. sehingga peneliti dapat mengetahui pelayanan yang diberikan pegawai tingkat kecamatan pada masyarakat dilihat dari efektivitas pemimpin (camat) serta dilihat dari intensi pelaksanaan etika kerja yang dimiliki oleh setiap pegawai.

Pendekatan yang digunakan dalam penelitian ini adalah pendekatan kuantitatif.

Pada penelitian ini, penulis akan membahas mengenai variabel Efektivitas Kepemimpinan $\left(X_{1}\right)$, Intensi Pelaksanaan Etika Kerja $\left(X_{2}\right)$ sebagai variabel independent atau variabel bebas serta Kualitas Pelayanan (Y) sebagai variabel dependent atau variabel terikat.

Populasi dalam penelitian ini adalah pegawai tingkat kecamatan di Kota Bandung yang berjumlah 90 orang.

penelitian ini menggunakan dua tekhnik utama pengumpulan data yaitu studi kepustakaan dan kuesioner.

Teknik analisis data yang digunakan dalam penelitian ini dengan menggunakan pendekatan desktiptif, hal ini dilakukan untuk mendeskripsikan atau menggambarkan tentang variabel efektivitas kepemimpinan, intensi pelaksanaan etika kerja, serta kualitas pelayanan pada pegawai tingkat kecamatan di kota Bandung. Untuk menguji hipotesis penelitian dilakukan dengan menggunakan model analisis jalur (path analysis) dan pengolahan data menggunakan Microsoft Exel dan SPSS 21 for windows.

\section{HASIL DAN PEMBAHASAN}

1. Pengaruh Efektivitas Kepemimpinan Terhadap Intensi Pelaksanaan Etika Kerja.

Berdasarkan data yang diolah, didapat nilai sebesar 0.783 atau sebesar $78,3 \%$ yang menunjukan bahwa adanya pengaruh langsung dari varibel efektivitaas kepemimpinan (X1) terhadap variabel 
Intensi pelaksanaan etika kerja (X2). Hubungan tersebut dikatakan tinggi.

Temuan penelitian ini didukung dengan data rata-rata variabel intensi pelaksanaan etika kerja indikator norma subjektif. Dimana norma subjektif ini, individu dapat melakukan sesuatu hal bila didorong dan didukung oleh orang terdekatnya dalam penelitian ini pegawai kantor kecamatan didorong dan didukung oleh pimpinannya (camat). selain itu kepemimpinan yang efektif dan strategis. dapat mempengaruhi perilaku orang lain dengan menggunakan gaya-gaya kepemimpinannya, gaya kepemimpinan tersebut dapat berupa perilaku, sifat yang dimiliki oleh pemimpin tersebut yang ditunjukan kepada orang lain atau bawahannya. Dengan demikian dalam penelitian ini pimpinan (camat) dapat di kota Bandung mampu mempengaruhi bawahannya untuk mendorong dan mendukung hadir di kantor dengan tepat waktu, memberikan pelayanan walaupun jam pelayanan sudah berakhir, menyelesaikan pekerjaan sesuai dengan tugasnya, menyelesaikan pekerjaan sesuai dengan permintaan dan kebutuhan masyarakat, menyelesaikan keluhan dan memberikan pelayanan yang sesuai dengan kebutuhan masyarakat.

2. Pengaruh Efektivitas Kepemimpinan terhadap Kualitas Pelayanan

Berdasarkan data yang telah diolah, diketahui dalam penelitian ini bahwa efektivitas kepemimpinan memiliki pengaruh langsung sebesar 0.413 atau 41,3\% dimana nilai tersebut memiliki arti pengaruh efektivitas kepemimpinan terhadap Kualitas pelayanan cukup. Begitu pula dengan hubungan tidak langsung yang sebesar 0,338 atau sebesar 33,8\% dimana memiliki hubungan yang rendah. Namun berdasarkan pada analisis deskriptif bahwa efektivitas kepemimpinan (camat) yang berada di kota Bandung berada dalam kategori baik dengan jumlahskor 4.518. Hal ini mengisyaratkan bahwa sebagian besar pegawai kecamatan ditiap kecamatan kota Bandung menyatakan bahwa efektivitas kepemimpinan seorang camat sudah baik.

3. Pengaruh Intensi Pelaksanaan etika kerja terhadap Kualitas Pelayanan.
Pengaruh langsung yang dimiliki variabel Intensi Pelaksanaan etika kerja terhadap Kualitas Pelayanan adalah sebesar $0.432=43,2 \%$. Berdasarkan data tersebut maka dapat dikatakan bahwa pengaruh Intensi Pelaksanaan etika kerja terhadap Kualitas Pelayanan terbilang cukup. Berkaitan dengan data hasil penelitian diatas, hal senada di dikemukakan oleh Ismail dan Zain (2008), yaitu kontrol perilaku merupakan persepsi individu mengenai kontrol yang dimiliki individu tersebut sehubungan dengan tingkah laku tertentu. Kontrol perilaku merupakan keyakinan tentang ada atau tidaknya faktor-faktor yang memfasilitasi dan menghalangi individu untuk melakukan suatu perilaku. Kontrol perilaku ditentukan oleh pengalaman masa lalu individu dan juga perkiraan individu mengenai seberapa sulit atau mudahnya untuk melakukan suatu perilaku. Pengalaman masa lalu individu terhadap suatu perilaku bisa dipengaruhi oleh informasi yang didapat dari orang lain, misalnya dari pengalaman orang-orang yang dikenal seperti keluarga, pasangan dan teman, dalam penelitian ini pimpinan dan rekan kerja yang menjadi orang terdekat bagi pegawai ditingkat kecamatan.

4. Pengaruh Efektivitas kepemimpinan dan Intensi Pelaksanaan etika kerja terhadap Kualitas Pelayanan

Pengaruh langsung yang dimiliki variabel Efektivitas Kepemimpinan dan Intensi Pelaksanaan etika kerja terhadap kualitas pelayanan dilihat dari hasil $R_{\text {square }}$ 0,637 atau sebesar 63,7\%. Hasil tersebut bila merujuk pada pengklasifikasian sugiono (2010:27) hasil tersebut dikatakan tinggi. Sisanya sebesar 36,3\% dipengaruhi oleh faktor-faktor lain yang tidak dapat dijelaskan dalam penelitian.

Dalam penelitian ini adalah pegawai tingkat kecamatan di kota Bandung mampu atau tidaknya dapat melayani masyarakat dan memahami betul apa yang menjadi tugasnya, merasa nyaman dan ingin memberikan yang terbaik bagi tempat bekerjanya akan dipengaruhi oleh bagaimana seorang pimpinan (camat) berperilaku dan meberikan contoh yang baik pada bawahannya.

\section{KESIMPULAN}


Berdasarkan analisis dan pembahasan hasil penelitian, maka didapat kesimpulan mengenai penelitian ini adalah sebagai berikut :

1. Efektivitas Kepemimpinan berpengaruh positif terhadap Kualitas Pelayanan, namun pengaruhnya dikategorikan cukup. Artinya seorang pimpinan (camat) berpengaruh terhadap pegawai dalam memberikan pelayanan kepada masyarakat. Dengan demikian baik buruknya suatu kualitas pelayanan dapat dijelaskan oleh Efektivitas kepemimpinan.

2. Efektivitas Kepemimpinan berpengaruh positif terhadap Intensi pelaksanaan etika kerja. Pengaruh langsung dari variabel efektivitas kepemimpinan pada variabel Intensi Pelaksanaan Etika kerja memiliki pengaruh yang kuat. Pimpinan (camat) dan teman sekantor berpengaruh terhadap kualitas pelayanan yang diberikan oleh pegawai kecamatan terhadap masyarakat.

3. Intensi Pelaksanaan Etika kerja berpengaruh positif terhadap Kualitas Pelayanan. Artinya bahwa tingkah laku yang ditampilkan dalam penelitian ini adalah tingkah laku melaksanakan aturan-aturan di kantor kecamatan berpengaruh terhadap Kualitas Pelayanan. Pengaruh yang dimiliki oleh variabel Intensi Pelaksanaan Etika Kerja pada variabel Kualitas Pelayanan dikategorikan cukup.

4. Efektivitas Kepemimpinan dan Intensi Pelaksanaan Etika kerja berpengaruh positif terhadap Kualitas Pelayanan, pengaruhnya termasuk kategori kuat Dengan demikian baik buruknya kualitas pelayanan dapat dijelaskan oleh efektivitas kepemimpinan dan Intensi Pelaksanaan Etika kerja.

\section{REKOMENDASI}

Berdasarkan analisis dan pembahasan hasil penelitian, maka penulis memberikan saran kepada lembaga terkait ataupun pada peneliti selanjutnya terkait dengan penelitian mengenai pengaruh efektivitas kepemimpinan dan intensi pelaksaan etika kerja terhadap kualitas pelayanan. Adapun sarannya adalah sebagai berikut :
1. Pegawai kecamatan seharusnya lebih banyak melakukan sosialisasi terhadap masyarakat saat masyarakat akan membuat dokumen kependudukan yang merupakan pelayanan dari kecamatan sehingga masyarakat tidak harus sampai berulang kali datang ke kecamatan hanya untuk melengkapi persyaratan dan berkas-berkas yang telah ditentukan.

2. Sebagian besar pegawai kecamatan hanya menyelesaikan sekolahnya hingga Sekolah Menengah Umum (SMU) sehingga pemahaman pekerjaannya harus senantiasa dilatih dan dikembangkan. Sehingga sedikit mengurangi pelayanan yang harus membuat masyarakatnya beberapa kali datang ke kantor kecamatan untuk menambah persyaratan yang dibutuhkan.

3. Pimpinan (Camat) sebaiknya memberikan contoh untuk hadir tepat waktu agar pegawai kecamatan pun bisa hadir tepat waktu sehingga tidak mengurangi dan bahkan memperbaiki jam pelayanannya sesuai informasi yang diberikan kepada masyarakat.

4. Pimpinan (Camat) dan pegawainya sebaiknya dapat membuat pengklasifikasian lebih rinci mengenai capaian hasil kerja, tidak hanya tercapai atau tidak tercapainya suatu targetan sehingga dapat memperbaiki pelayanan pada masyarakat dengan lebih baik lagi.

5. Seluruh pegawai kecamatan dan pimpinan (Camat) melaksanakan pelayanan prima yang sesuai dengan konsep dan fungsinya bagi masyarakat setempat.

6. Bagi peneliti selanjutnya, berdasarkan data yang diperoleh diketahui ada 36,3\% faktor lain yang mempengaruhi Kualitas Pelayanan yang tidak diteliti oleh penulis, sehingga dapat dijadikan bahan rujukan kepada peneliti selanjutnya untuk lebih komprehensif dalam meneliti Kualitas Pelayanan.

\section{DAFTAR PUSTAKA}

Afrizal J, Rozy. 2009. Kualitas Pelayanan Publik Kecamatan setelah Perubahan Kedudukan dan 
Fungsi Camat sebagai Perangkat Daerah: Jurnal Administrasi dan Organisasi. Vol 2 no 2.

Ajzen, Icek, 2005, Attitudes, Personality, and Behavior, Edisi kedua, New York: Open University Press.

Arikunto, Suharsimi.2002. Prosedur Penelitian: Suatu Pendekatan Praktek. Edisi Revisi V. Jakarta: Rineka Cipta

Budiman, Arif. 1996.Fungsi Tanah dan Kapitalis. Jakarta : Sinar Grafika.

Chaplin, J.P., 2004, Kamus Lengkap Psikologi, cet. ke-9, Penerjemah: Dr. Kartini Kartono, Jakarta: Rajawali Pers.

Fishbein, Martin, \& Icek Ajzen, 1975, Belief, Attitude, Intention, dan Behavior: An Introduction to Theory and Research, Massachusetts: AddisonWesley Publishing Company.

Kotler, Philip. 1995. Manajemen Pemasaran: Analisis, Perencanaan, Implementasi dan Penegndalian. Terjemahan Ancella Anitawati Hermawan. Jakarta: Salemba Empat

Kotler, Philip \& Amstrong Gary.1997. Principles of Marketing, Seventh Edition. Prentice Hall, Inc., Simon and Schuster (Asia) Pte. Ltd

Kotler, Philip and Gary Armstrong (2012). Principle of Marketing, Fourteenth Edition. Pearson Education Limited, England.

Lovelock, Christopher and Lauren Wright (2002). Principles of Service Marketing and Management. Second Edition. Pearson Education International, Inc. Prentice Hall.

Lupiyoadi, Rambat dan A. Hamdani. (2011). Manajemen Pemasaran Jasa. Edisi Dua. Salemba Empat, Jakarta.

Sugiono. 2002. Metode Penelitian Bisnis. Bandung : Alfabeta

Sugiono. 2008. Metode Penelitian Kuantitatif, Kualitatif dan R\&D. Bandung: Alfabeta

Tjiharjadi, Semuji. 2007. To Be a Great Leader. Yogyakarta: Andi

Tjiptono, Fandy\& Chandra, Gregorius. 2005. Service Quality Satisfaction. Yogyakarta: Andi Offset.

Yamit, Zulian. 2004. Manajemen Kualitas Produk dan Jasa. Yogyakarta.Ekonisia
Yukl, Gary. 2005. Kepemimpinan dalam Organisasi. Edisi ke 5. Jakarta : Indeks 